\title{
Awareness On Recent Advances in Gingival Retraction Materials During Impression Making Among Undergraduate Dental Students - A Questionnaire Survey
}

\author{
M. Ovia', Revathi Duraisamy² and Dhanraj Ganapathy ${ }^{3}$ \\ ${ }^{1}$ Saveetha Dental College, Saveetha Institute of Medical and Technical \\ Sciences, Saveetha University Chennai, India. \\ ${ }^{2}$ Senior Lecturer, Department of Prosthodontics, Saveetha Dental College, Saveetha \\ Institute of Medical and Technical Sciences, Saveetha University Chennai-77, India. \\ ${ }^{3}$ Professor and Head, Department of Prosthodontics, Saveetha Dental College and Hospitals, \\ Saveetha Institute of Medical and Technical Sciences, Saveetha University, Chennai, India
}

\section{ABSTRACT}

The aim of this survey was to create an awareness on recent advances in gingival retraction materials during impression making. A set of 10 questionnaires were circulated among the undergraduate (UG) students of Saveetha Dental College which was done in an online forum Survey planet to avoid discussion and false results, thereby no bias is evidenced in this study. A response of 100 UG students was collected and datas were entered to an Excel sheet followed by statistical analysis done in SPSS by IBM. The statistical test used is Chi-square test. From the survey we obtained that 66\% of the students who attended the survey were third year students, 11\% final years and 23\% were CRRI. 80\% of them were aware of recent advances in gingival retraction materials during impression making, 77\% were aware of retraction cord, $76 \%$ were aware of the disadvantage of retraction cord, 78\% were aware of the time consumption of retraction cord, 69\% were aware of gingifoam, 70\% were aware of Expasyl paste, 66\% of were aware of Comprecap, 69\% were aware of magic foam, 59\% of them use Comprecap, 75\% of them were aware of the expense of advanced materials. There was a significant association between the awareness of recent advances in the gingival retraction materials and year of study $(p<0.05)$. The study concluded that UG students were aware of the recent advances in gingival retraction materials used in impression making which should be used in their daily clinical practice.

KEY WORDS: EXPASYL; GEL-CORD; GINGIFOAM; MAGIC FOAM CORD; MERCOCEL.

\section{ARTICLE INFORMATION}

*Corresponding Author: revathid.sdc@saveetha.com

Received 1st Aug 2020 Accepted after revision 29th Sep 2020

Print ISSN: 0974-6455 Online ISSN: 2321-4007 CODEN: BBRCBA

Thomson Reuters ISI Web of Science Clarivate Analytics USA and Crossref Indexed Journal

$$
\begin{aligned}
& \text { Clarivate } \\
& \text { Analytics }
\end{aligned}
$$

NAAS Journal Score 2020 (4.31) SJIF: 2020 (7.728)

A Society of Science and Nature Publication,

Bhopal India 2020. All rights reserved.

Online Contents Available at: http//www.bbrc.in/

Doi: $h t t p: / / d x$.doi.org/10.21786/bbrc/13.8/200 


\section{INTRODUCTION}

Gingival retraction is a reversible lateral and vertical deflection of the marginal gingiva away from the tooth which was an important and mandatory procedure while fabricating indirect restorations. They are frequently placed in the gingival sulcus for aesthetic and functional reasons. Hence, that must be reproduced accurately in the impression making and any failure results in a compromised marginal integrity, recurrent caries or gingival inflammation and periodontal breakdown(Rosenstiel, Land and Fujimoto, 2006).Gingival retraction's goals included adequate bulk flow of material should flow into the sulcus inorder to accurately record margin details and to prevent impression material from the sulcus of the gingiva, also to record the unprepared tooth surface apical to the finish line (Donovan and Chee, 2004). The minimum lateral retraction should be $0.2 \mathrm{~mm}$, a small amount of impression material may flow beyond the prepared margin.

Displacement cords were supplied in three designs, namely, twisted cords, braided cords, \& knitted cords, its selection is determined by the operator's preference since it usually brings about the desired Gingival displacement. Major disadvantages are its high expenses, thickness of the paste which makes it difficult to express into the sulcus and big metal tips for interproximal areas(Ayo-Yusuf, Driessen and Botha, 2005). Another system on the docks is the matrix impression system, a three-impression procedure which uses three viscosities of impression technique and attempts to overcome the deficiencies of the older systems to incorporate its best features(Hansen, Tira and Barlow, 1999).

Gingitrac(Chao et al., 2017) is a gingival-retraction paste system which is a preloaded syringe with paste which can be applied around the margins. This paste contains aluminum sulfate as an astringent and a hemostatic agent can be applied prior to its use. For single tooth use, a cap is used to apply pressure, after application of paste. Magic foam cord (Wassell et al., 2018) is another new non-hemostatic gingival-retraction system which was the first expanding vinyl polysiloxane material designed for retraction of the gingival sulcus without the potential traumatic and time-consuming packing of retraction cord. Mercocel (Ferrari, Cagidiaco and Ercoli, 1996) is a new retraction material that is used to displace gingival tissues without tissue damage before impression making. Merocel retraction strips are synthetic material consisting of polymer hydroxylate polyvinyl acetate which creates a net-like strip without debris or free fragment and its placement does not require use of local anesthesia which helps in careful management of the delicate gingival tissues with improved management of the treatment.

Racegel is another hemostatic agent that controls bleeding before and during impression-taking and crown placement. Due to its thermodynamic characteristics, its viscosity increases upon contact with the tissue, providing access to the gingival margin. The surgical techniques are Rotary curettage(Hobo, Shillingburg and Whitsett, 1976) which is performed on healthy tissue where the portion of sulcular epithelium is excised. Lasers were employed which causes tissue-coagulation facilitating hemostasis tissue removal and sulcular epithelium is removed. Commonly used soft-tissue lasers for gingival displacement include $\mathrm{CO}_{2}$ lasers, diode lasers, erbium lasers, etc(Tao et al., 2018). Mechanical retraction techniques are contraindicated around implants, except when the patient's gingival shallow sulcus depth, thick gingival biotype(Bennani, Schwass and Chandler, 2008).

Previously our department has published extensive research on various aspects of prosthetic dentistry ('Evaluation of Corrosive Behavior of Four Nickelchromium Alloys in Artificial Saliva by Cyclic Polarization Test:An in vitro Study', 2017; Ganapathy, Kannan and Venugopalan, 2017; Jain, 2017a, 2017b; Ranganathan, Ganapathy and Jain, 2017; Ariga et al., 2018; Gupta, Ariga and Deogade, 2018; Anbu et al., 2019; Ashok and Ganapathy, 2019; Duraisamy et al., 2019; Varghese, Ramesh and Veeraiyan, 2019)(Mahendran et al., 2017; S et al., 2017; V et al., 2017), this vast research experience has inspired us to conduct a survey about awareness on recent advances in gingival retraction materials during impression making. Thus, the study aimed in finding out the awareness of recent advances in gingival retraction materials during impression making among UG students.

\section{MATERIAL AND METHODS}

This study was done as a questionnaire survey which was done in December 2019 and answered by the UG students of the Saveetha Dental College. Students who were involved in the survey included third years, final years and CRRI (Interns). The survey involved completion of a predesigned questionnaire containing 2 sections with a total of ten questions. Set- 1 questions were about the demographic details like their Name, gender and the year of study. Questionnaire was sent through an online forum Survey planet only to students practicing in clinics (Third years, Final years and CRRIs). Set-2 included questions about the awareness of recent advances in gingival materials during impression making, awareness on Retraction cord, Gingifoam, Expasyl paste, Compre cap, Magic foam, disadvantages of overpacking and awareness of recent advances in gingival retraction materials during impression making, also their expenses and were sent in an online forum Survey planet to avoid discussion and false results, thereby no bias is evidenced in this study. Age, Gender and the responses were considered as Inclusion criteria.

After applying inclusion criteria a data from 100 responses were collected and tabulated in an Excel sheet followed by statistical analysis done in SPSS by IBM. The statistical test used is Chi-square test. Association was done between the year of study and students awareness about the recent advances in gingival retraction materials 
during impression making, Retraction cord, Gingifoam, Expasyl paste, Compre cap, Magic foam, disadvantages of retraction cord as its overpacking and awareness of recent advances in gingival retraction materials during impression making and their expenses.

The participants were asked to put the responses in the questionnaire on Survey planet. The completed questionnaires were carefully checked by the investigator.

Attachment I: Questionnaire:

Section I: Name -

Gender -

Year of study -

\section{Section II : Questionnaire-(Table 1)}

\begin{tabular}{|c|c|c|c|}
\hline S.No & Questions & Choices & Percent \\
\hline 1. & $\begin{array}{l}\text { Are you aware of recent advances in gingival } \\
\text { retraction materials during impression making? }\end{array}$ & $\begin{array}{l}\text { a)Yes } \\
\text { b)No }\end{array}$ & $\begin{array}{l}80 \% \\
20 \%\end{array}$ \\
\hline 2. & Are you aware of retraction cord? & $\begin{array}{l}\text { a)Yes } \\
\text { b)No }\end{array}$ & $\begin{array}{l}77 \% \\
23 \%\end{array}$ \\
\hline 3. & $\begin{array}{l}\text { Do you think overpacking of retraction causes a } \\
\text { major disadvantage? }\end{array}$ & $\begin{array}{l}\text { a)Yes } \\
\text { b)No }\end{array}$ & $\begin{array}{l}76 \% \\
24 \%\end{array}$ \\
\hline 4. & Is usage of retraction cord time consuming? & $\begin{array}{l}\text { a)Yes } \\
\text { b)No }\end{array}$ & $\begin{array}{l}78 \% \\
22 \%\end{array}$ \\
\hline 5. & $\begin{array}{l}\text { Are you aware of gingifoam which works on the } \\
\text { principle of dilation of the gingival sulcus by expansion? }\end{array}$ & $\begin{array}{l}\text { a)Yes } \\
\text { b)No }\end{array}$ & $\begin{array}{l}69 \% \\
31 \%\end{array}$ \\
\hline 6. & $\begin{array}{l}\text { Are you aware that expasyl paste which is used in } \\
\text { retraction requires minimal time and force } \\
\text { when compared to retraction cord? }\end{array}$ & $\begin{array}{l}\text { a)Yes } \\
\text { b)No }\end{array}$ & $\begin{array}{l}70 \% \\
30 \%\end{array}$ \\
\hline 7. & $\begin{array}{l}\text { Are you aware of the compre cap used in retraction } \\
\text { technique in impression making? }\end{array}$ & $\begin{array}{l}\text { a)Yes } \\
\text { b)No }\end{array}$ & $\begin{array}{l}66 \% \\
34 \%\end{array}$ \\
\hline 8. & $\begin{array}{l}\text { Are you aware of the magic foam cord used that gives } \\
\text { the best sulcus enlargement } \\
\text { which can give the perfect impression? }\end{array}$ & $\begin{array}{l}\text { a)Yes } \\
\text { b)No }\end{array}$ & $\begin{array}{l}69 \% \\
31 \%\end{array}$ \\
\hline 9. & $\begin{array}{l}\text { What are the recent advances of gingival retraction } \\
\text { you use in your daily practice? }\end{array}$ & $\begin{array}{l}\text { a) Magic foam } \\
\text { b) Compre cap } \\
\text { c) Expasyl }\end{array}$ & $\begin{array}{l}30 \% \\
59 \% \\
11 \%\end{array}$ \\
\hline 10. & $\begin{array}{l}\text { Do you agree that the recent gingival retraction } \\
\text { method of impression taking is most expensive? }\end{array}$ & $\begin{array}{l}\text { a)Yes } \\
\text { b)No }\end{array}$ & $75 \%$ \\
\hline
\end{tabular}

Figure 1: Bar graph shows the percentage of students who attempted the survey, where $\mathrm{X}$-axis represents the Year of study and Y-axis represents the percentage of students who filled the survey. Out of which 66\% (indigo) of them were third year students, 11\% (gray) of them were final years and 23\% (blue) of them were CRRI (Interns).

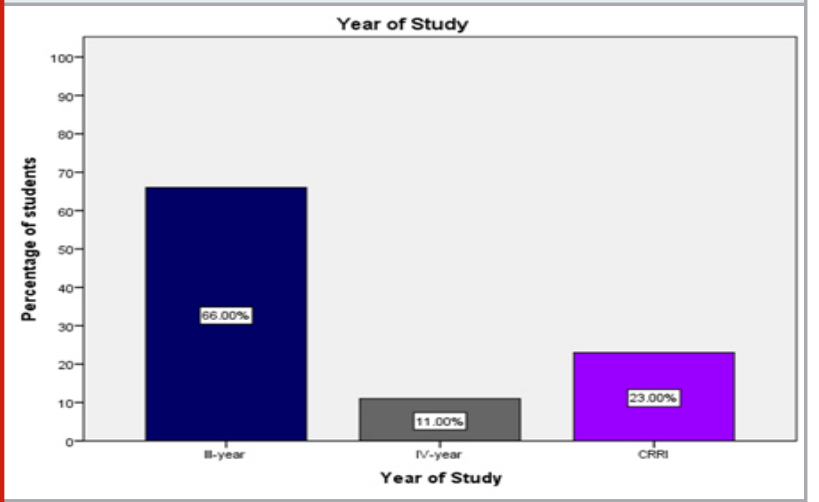

\section{RESULTS AND DISCUSSION}

From the survey we obtained that 66\% of the students who attended the survey were third year students, 11\% final years and 23\% were CRRI (Figure-1). 80\% of the students were aware of recent advances in gingival retraction materials during impression making of which 57\% were third years which was higher comparatively with a significant association of year of study with awareness of recent advances in gingival retraction materials during impression making( $(\mathrm{p}<0.05)$ (Figure-2). $77 \%$ of the students were aware of retraction cord of which 54\% were third years which was higher comparatively with a significant association of year of study with awareness on retraction cord $(\mathrm{p}<0.05)$ (Figure-3).

$76 \%$ of the students were aware of the disadvantage of retraction cord of which 53\% were third years which was higher comparatively with a significant association 
of year of study with awareness on disadvantage of retraction cord as its overpacking $(\mathrm{p}<0.05)$ (Figure-4). $78 \%$ of the students were aware of the time consumption of retraction cord of which 56\% were third years with a significant association of year of study with awareness on time consumption of retraction cord $(p<0.05)$ (Figure-5). $69 \%$ of the students were aware of gingifoam of which $49 \%$ were third years with a significant association of year of study with awareness on gingifoam $(\mathrm{p}<0.05)$ (Figure-6).

Figure 2: Bar graph shows the association between the year of study of students and the awareness on recent advances in gingival retraction materials during impression making where, $\mathrm{X}$-axis represents the year of study of students and $\mathrm{Y}$-axis represents the number of students who filled the survey. $80 \%$ of the students(blue) were aware of recent advances in gingival retraction materials during impression making, of which 57\% were third years. Chisquare test was performed(Chi-square value-10.413a , $\mathrm{p}=0.005$ ) which showed a significant association of year of study with awareness of recent advances in gingival retraction materials during impression making $(p<0.05)$.

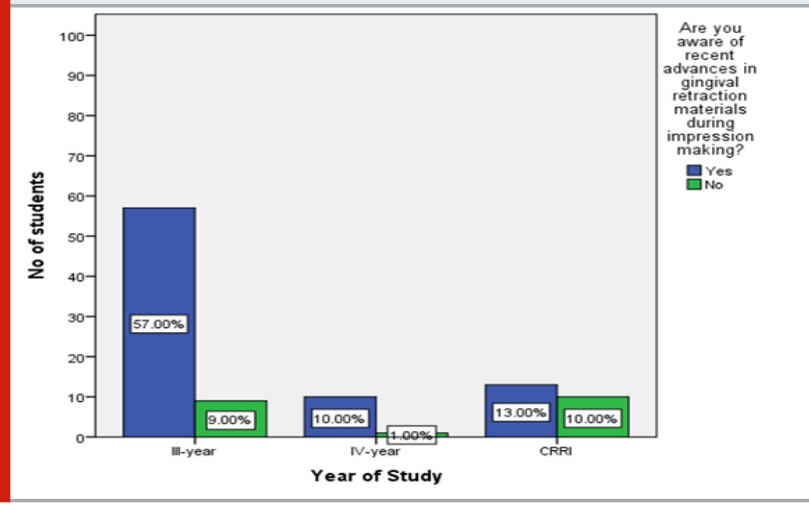

Figure 3: Bar graph shows the association between the year of study and awareness on gingival retraction cord where, $\mathrm{X}$-axis represents the year of study of students and $\mathrm{Y}$-axis represents the number of students who filled the survey. 77\% of the students(blue) were aware of retraction cord of which 54\% were third years. Chi-square test was performed(Chi-square value $-7.513 \mathrm{a}, \mathrm{p}=0.023$ ) which showed a significant association of year of study with awareness on retraction cord $(\mathrm{p}<0.05)$.

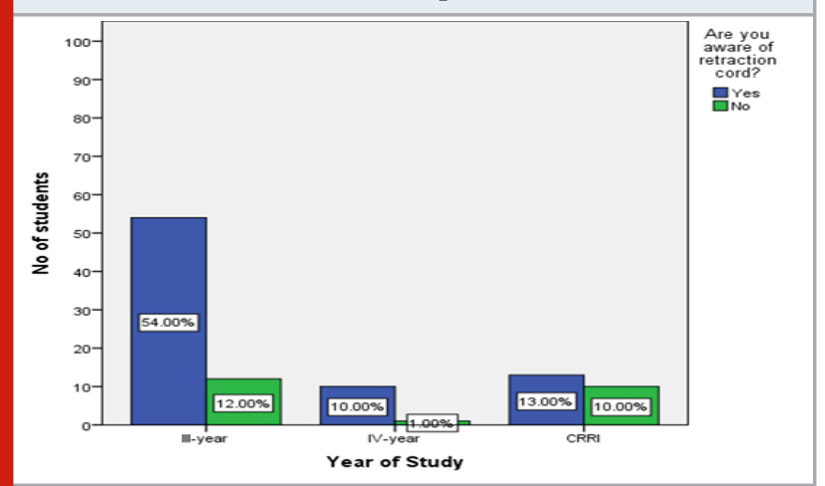

Figure 4: Bar graph shows the association between the year of study and awareness on disadvantage of retraction cord when it is overpacked, where $\mathrm{X}$-axis represents the year of study of students and Y-axis represents the number of students who filled the survey. $76 \%$ of the students(blue) were aware that the disadvantage of retraction cord is its overpacking of which 53\% were third years. Chi-square test was performed(Chi-square value - 6.795a, $\mathrm{p}=0.033$ ) which showed a significant association of year of study with awareness on disadvantage of retraction cord as its overpacking $(\mathrm{p}<0.05)$.

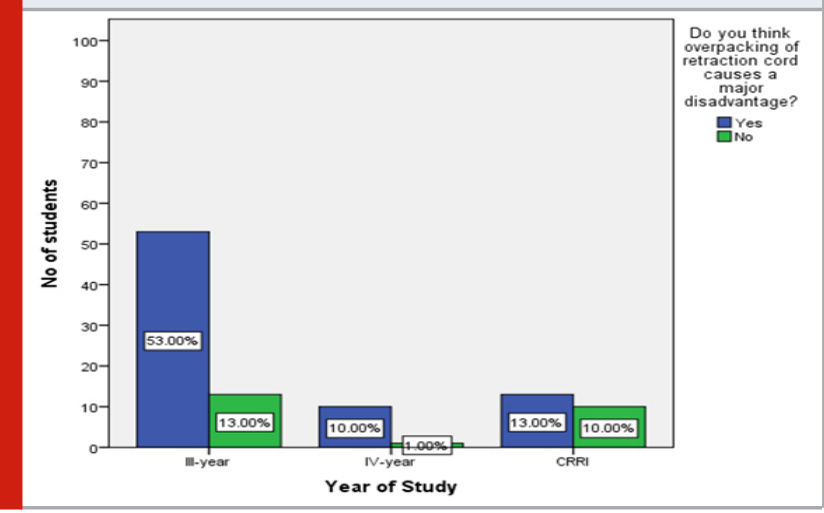

Figure 5: Bar graph shows the association between the year of study and the awareness on time consumption of retraction cord, where $\mathrm{X}$-axis represents the year of study of students and Y-axis represents the number of students who filled the survey. $78 \%$ of the students(blue) were aware that retraction cord is a time consuming procedure of which 56\% were third years. Chi-square test was performed(Chi-square value $-11.812 \mathrm{a}, \mathrm{p}=0.003$ ) which showed a significant association of year of study with awareness on time consumption of retraction cord $(\mathrm{p}<0.05)$.

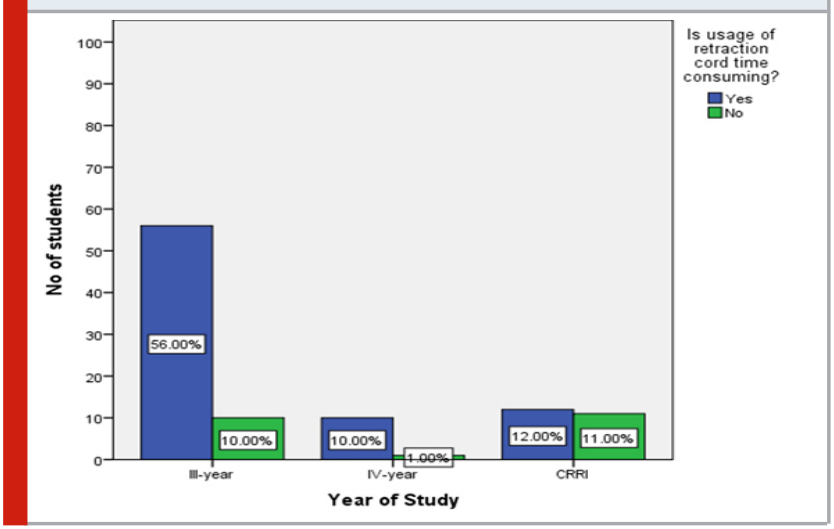

$70 \%$ of the students were aware of Expasyl paste of which 49\% were third years with a significant association of year of study with awareness on Expasyl paste $(p<0.05)$ (Figure-7). 66\% of the students were aware of Comprecap of which $45 \%$ were third years with a significant association of year of study with awareness on Comprecap $(\mathrm{p}<0.05)$ (Figure-8). 69\% of the students were aware of magic foam of which $49 \%$ were third years with 
a significant association of year of study with awareness on Magic Foam ( $<<0.05)$ (Figure-9). 59\% of them use Comprecap in their daily clinical practice of which $34 \%$ were third years with a significant association of year of study with the recent materials they use in their daily practice $(p<0.05)$.(Figure-10). 75\% of the students were aware of the expense of advanced materials of which $53 \%$ were third years with a significant association of year of study with their awareness on the expense of advanced materials $(\mathrm{p}<0.05)$ (Figure-11).

Figure 6: Bar graph shows the association between the year of study and the awareness on gingifoam and its working principle where, $\mathrm{X}$-axis represents the year of study of students and Y-axis represents the number of students who filled the survey. $69 \%$ of the students(blue) were aware of gingifoam of which $49 \%$ were third years. Chi-square test was performed (Chi-square value - 10.320a , $p=0.006$ ) which showed a significant association of year of study with awareness on gingifoam $(p<0.05)$.

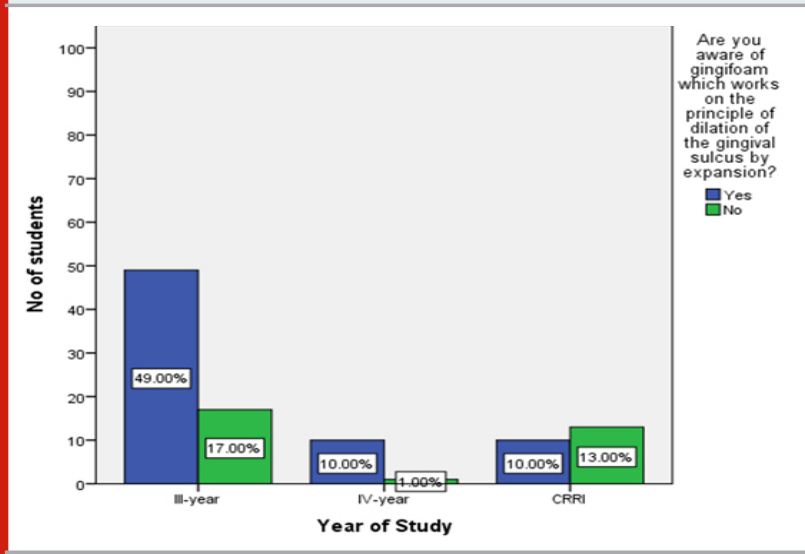

Figure 7: Bar graph shows the association between the year of study and the awareness on Expasyl paste and its convenience where, $\mathrm{X}$-axis represents the year of study of students and Y-axis represents the number of students who filled the survey. $70 \%$ of the students(blue) were aware of expasyl paste of which $49 \%$ were third years. Chi-square test was performed(Chi-square value $-8.241 \mathrm{a}, \mathrm{p}=0.016$ ) which showed a significant association of year of study with awareness on Expasyl paste $(p<0.05)$.

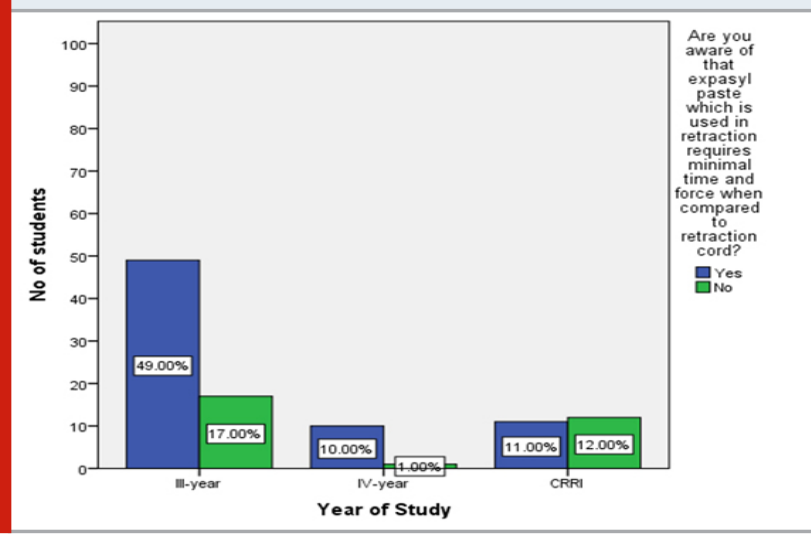

Figure 8: Bar graph shows the association between the year of study and the awareness on Comprecap, where, $\mathrm{X}$-axis represents the year of study of students and Y-axis represents the number of students who filled the survey. $66 \%$ of the students(blue) were aware of comprecap of which $45 \%$ were third years. Chi-square test was performed(Chi-square value - 6.567a , p=0.037) which showed a significant association of year of study with awareness on Comprecap $(\mathrm{p}<0.05)$.

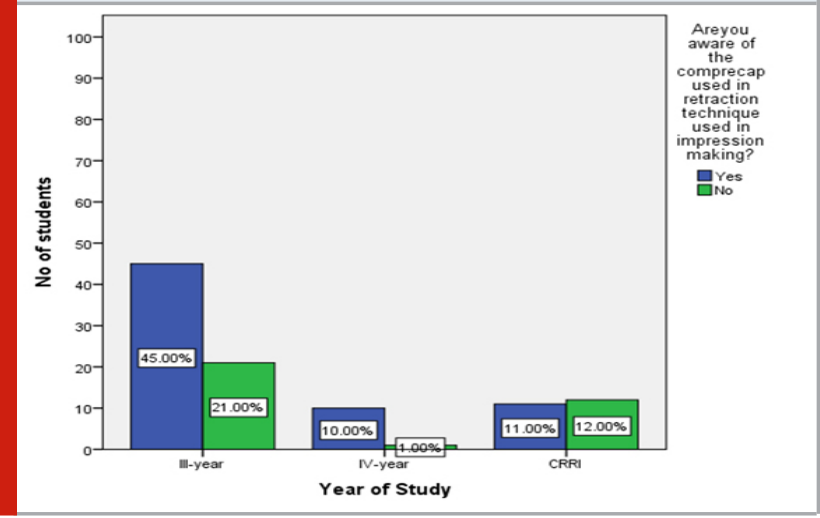

Figure 9: Bar graph shows the association between the year of study and the awareness on Magic Foam and its effectiveness where, $\mathrm{X}$-axis represents the year of study of students and Y-axis represents the number of students who filled the survey. $69 \%$ of the students(blue) were aware of Magic foam of which 49\% were third years. Chi-square test was performed(Chi-square value $-10.320 a, p=0.006$ ) which showed a significant association of year of study with awareness on Magic Foam $(p<0.05)$.

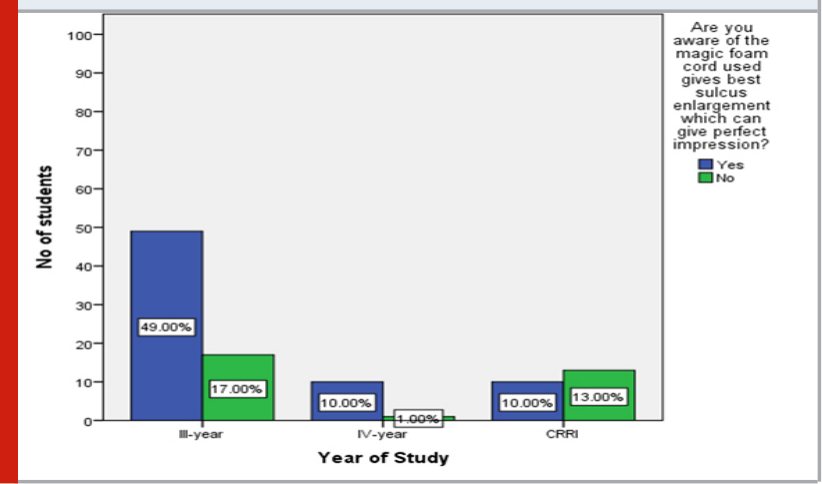

From the survey we obtained that $66 \%$ of the students who attended the survey were third year students, 11\% final years and 23\% were CRRI. 80\% of them were aware of recent advances in gingival retraction materials during impression making. Donovan TE et al(Donovan and Chee, 2004) also found a similar study where dental practitioners were more aware(85\%) of recent advances in gingival retraction during impression making. 77\% were aware of retraction cord. Shivasakthy et al., (Shivasakthy, 2013) also found in their study that most of the dentists were aware of the retraction cords. Also Xhonga FA and Kannan A(Xhonga, 1971; Kannan and Venugopalan, 2018) found similar results. 76\% were 
aware of overpacking as a disadvantage of retraction cord.Al-Ani et al.,(Al-Ani et al., 2010) also supported our study stating overpacking as a disadvantage of retraction cord.

Figure 10: Bar graph shows the association between the year of study and the awareness on recent materials they use in their daily practice where, $\mathrm{X}$-axis represents the year of study of students and Y-axis represents the number of students who filled the survey. 59\% of them use Comprecap(Violet) in their daily clinical practice of which 34\% were third years. Chi-square test was performed(Chi-square value - 12.265a , p=0.015) which showed a significant association of year of study with the recent materials they use in their daily practice $(\mathrm{p}<0.05)$.

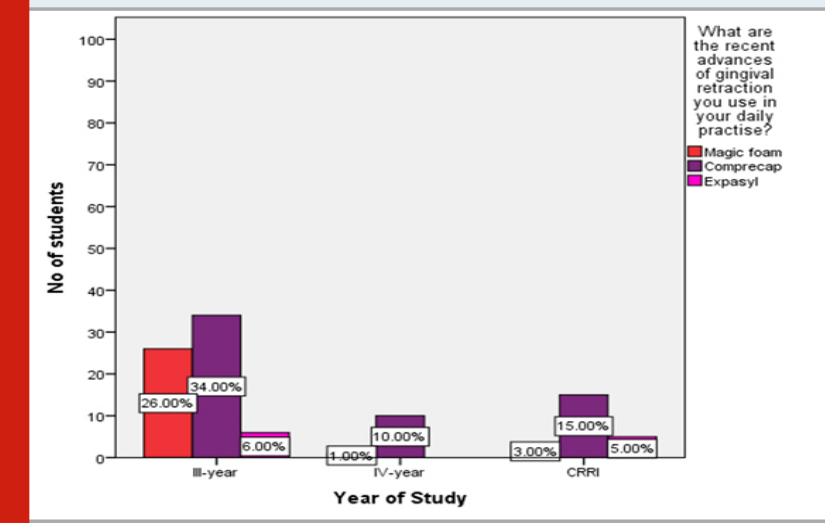

Figure 11: Bar graph shows the association between the year of study and the awareness on the expense of advanced materials where, $\mathrm{X}$-axis represents the year of study of students and Y-axis represents the number of students who filled the survey. 75\% of the students(blue) were aware of the expenses of advanced materials of which $53 \%$ were third years. Chi-square test was performed(Chisquare value- $8.866 \mathrm{a}, \mathrm{p}=0.012$ ) which showed a significant association of year of study with their awareness on the expense of advanced materials $(\mathrm{p}<0.05)$.

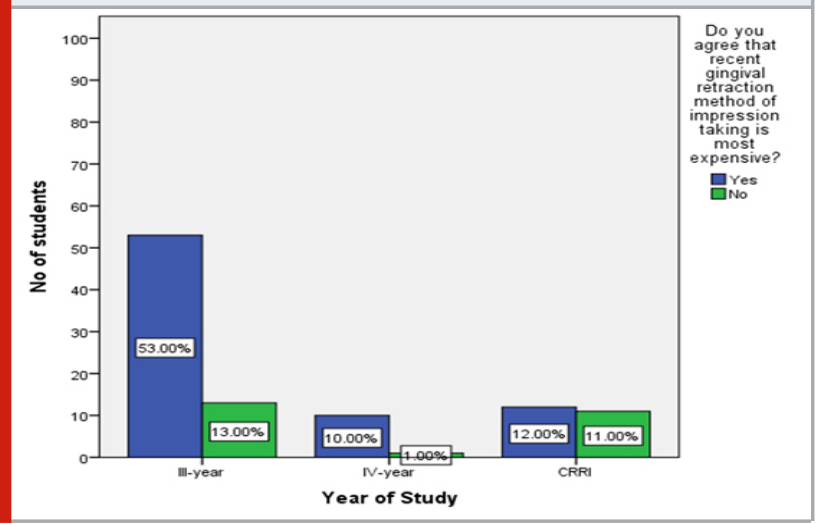

$78 \%$ were aware of the time consumption of retraction cord. Shamsuzzaman et al., (Shamsuzzaman et al., 2014) supported the study stating time consumption as one of the disadvantages using retraction cord. 69\% were aware of gingifoam which works on the principle of dilation of the gingival sulcus by expansion. Martignoni et al.,(Martignoni and Feinman, 1985) accepted our study results stating gingifoam usage for exposed margin. 70\% were aware of Expasyl paste which is used in retraction requires minimal time and force when compared to retraction cord. Abduljabbar and Al Baker found similar results to our study where he mentioned the impact of expasyl in gingival retraction paste on bond strength of self-etch and total-etch systems (Al Baker et al., 2015; Abduljabbar et al., 2019).66\% were aware of Comprecap , Livaditis in his study observed the same results of our study (Livaditis, 1998).

69\% were aware of magic foam cord which gives the best sulcus enlargement which can give a perfect impression. Al-Ani et al., (Al-Ani et al., 2010) also supported our study. 59\% of them use Comprecap which was higher compared to other retraction materials in impression making.Rosenstiel SF et al.,(Rosenstiel, Land and Fujimoto, 2006) also supported our study. 75\% of them were aware of the expense of advanced materials.Shaw et al (Shaw and Krejci, 1986) ,Reddy et al., (Reddy et al., 2016) supported our study stating the high expense in usage of recent advanced retraction materials. There was a significant association between the awareness of recent advances in the gingival retraction materials and year of study $(p<0.05)$.

\section{CONCLUSION}

The study concludes that Undergraduate students (3rd year,final year and CRRI) were aware of the recent advances in gingival retraction materials used in impression making. There was a significant association between the awareness of recent advances in the gingival retraction materials and year of study $(p<0.05)$. Since, gingival retraction is an important clinical procedure for soft tissue management and impression-making, reasonable advanced retraction materials should be used in every clinician's daily practice for obtaining best results.

\section{ACKNOWLEDGEMENTS}

I sincerely thank my Guide, Mentor, Department of Research \& IT Saveetha Dental College and Hospitals,Saveetha Institute Medical and Technical Sciences, Saveetha University for making me complete the research work.

\section{Conflicts of Interest: Nil}

\section{REFERENCES}

Abduljabbar, T. S. et al. (2019) 'Effects of Gingival Retraction Paste and Subsequent Cleaning with Hydrogen Peroxide on the Polymerization of Three Elastomeric Impression Materials: An In Vitro Study', Journal of prosthodontics: official journal of the American College of Prosthodontists, 28(6), pp. 709714. 
Al-Ani, A. et al. (2010) 'New Zealand dentists' use of gingival retraction techniques for fixed prosthodontics and implants', The New Zealand dental journal, 106(3), pp. 92-96.

Al Baker, A. M. A. et al. (2015) 'The Impact of Expasyl ${ }^{\circledR}$ Gingival Retraction Paste on the Bond Strength of Self-etch and Total-etch Systems', The journal of contemporary dental practice, 16(5), pp. 335-339.

Anbu, R. T. et al. (2019) 'Comparison of the Efficacy of Three Different Bone Regeneration Materials: An Animal Study', European journal of dentistry, 13(1), pp. 22-28.

Ariga, P. et al. (2018) 'Determination of Correlation of Width of Maxillary Anterior Teeth using Extraoral and Intraoral Factors in Indian Population: A Systematic Review', World Journal of Dentistry, 9(1), pp. 68-75. Ashok, V. and Ganapathy, D. (2019) 'A geometrical method to classify face forms', Journal of oral biology and craniofacial research, 9(3), pp. 232-235.

Ayo-Yusuf, 0. A., Driessen, C. H. and Botha, A. J. (2005) 'SEM-EDX study of prepared human dentine surfaces exposed to gingival retraction fluids', Journal of Dentistry, pp. 731-739. doi: 10.1016/j. jdent.2005.02.002.

8.Bennani, V., Schwass, D. and Chandler, N. (2008) 'Gingival retraction techniques for implants versus teeth: current status', Journal of the American Dental Association , 139(10), pp. 1354-1363.

Chao, Y.-C. et al. (2017) 'Surgical Site Assessment for Soft Tissue Management in Ridge Augmentation Procedures', The International Journal of Periodontics \& Restorative Dentistry, pp. e75-e83. doi: 10.11607/ prd.2097.

Donovan, T. E. and Chee, W. W. L. (2004) 'Current concepts in gingival displacement', Dental Clinics of North America, pp. 433-444. doi: 10.1016/j. cden.2003.12.012.

Duraisamy, R. et al. (2019) ‘Compatibility of Nonoriginal Abutments With Implants: Evaluation of Microgap at the Implant-Abutment Interface, With Original and Nonoriginal Abutments', Implant dentistry, 28(3), pp. 289-295.

Evaluation of Corrosive Behavior of Four Nickelchromium Alloys in Artificial Saliva by Cyclic Polarization Test:An in vitro Study' (2017) World Journal of Dentistry, 8(6), pp. 477-482.

Ferrari, M., Cagidiaco, M. C. and Ercoli, C. (1996) 'Tissue management with a new gingival retraction material: A preliminary clinical report', The Journal of Prosthetic Dentistry, pp. 242-247. doi: 10.1016/s00223913(96)90479-5.

Ganapathy, D. M., Kannan, A. and Venugopalan, S. (2017) 'Effect of Coated Surfaces influencing Screw
Loosening in Implants: A Systematic Review and Meta-analysis', World Journal of Dentistry, 8(6), pp. 496-502.

Gupta, P., Ariga, P. and Deogade, S. C. (2018) 'Effect of Monopoly-coating Agent on the Surface Roughness of a Tissue Conditioner Subjected to Cleansing and Disinfection: A Contact Profilometric Study', Contemporary clinical dentistry, 9(Suppl 1), pp. S122S126.

Hansen, P. A., Tira, D. E. and Barlow, J. (1999) 'Current methods of finish-line exposure by practicing prosthodontists', Journal of prosthodontics: official journal of the American College of Prosthodontists, 8(3), pp. 163-170.

Hobo, S., Shillingburg, H. T. and Whitsett, L. D. (1976) 'Articulator selection for restorative dentistry', The Journal of Prosthetic Dentistry, pp. 35-43. doi: 10.1016/0022-3913(76)90231-6.

Jain, A. R. (2017a) 'Clinical and Functional Outcomes of Implant Prostheses in Fibula Free Flaps', World Journal of Dentistry, 8(3), pp. 171-176.

Jain, A. R. (2017b) 'Prevalence of Partial Edentulousness and Treatment needs in Rural Population of South India', World Journal of Dentistry, 8(3), pp. 213-217.

Kannan, A. and Venugopalan, S. (2018) 'A systematic review on the effect of use of impregnated retraction cords on gingiva', Research Journal of Pharmacy and Technology, p. 2121. doi: 10.5958/0974360x.2018.00393.1.

Livaditis, G. J. (1998) 'Comparison of the new matrix system with traditional fixed prosthodontic impression procedures', The Journal of Prosthetic Dentistry, pp. 200-207. doi: 10.1016/s0022-3913(98)70216-1.

Mahendran, S. et al. (2017) 'Status of malocclusion among adults in rural areas', International Journal of Current Advanced Research, pp. 2958-2960. doi: 10.24327/ijcar.2017.2960.0153.

Martignoni, M. and Feinman, P. (1985) '[Gingival retraction using Gingifoam. Inflation exposes the margin]', Attualita dentale, 1(30), pp. 13-17.

Ranganathan, H., Ganapathy, D. M. and Jain, A. R. (2017) 'Cervical and Incisal Marginal Discrepancy in Ceramic Laminate Veneering Materials: A SEM Analysis', Contemporary clinical dentistry, 8(2), pp. 272-278.

Reddy, S. V. G. et al. (2016) 'Gingival displacement methods used by dental professionals: A survey', Journal of Orofacial Sciences, p. 120. doi: 10.4103/09758844.195909.

Rosenstiel, S. F., Land, M. F. and Fujimoto, J. (2006) Contemporary Fixed Prosthodontics. Elsevier Health Sciences.

Shamsuzzaman, M. et al. (2014) 'Effect of gingival 
retraction cord and retraction paste on gingival tissue in fixed prosthodontics impression', Update Dental College Journal, pp. 20-27. doi: 10.3329/updcj.v3i2.17995.

Shaw, D. H. and Krejci, R. F. (1986) 'Gingival retraction preference of dentists in general practice', Quintessence international, 17(5), pp. 277-280.

Shivasakthy, M. (2013) 'Comparative Study on the Efficacy of Gingival Retraction using Polyvinyl Acetate Strips and Conventional Retraction Cord - An in Vivo Study', JOURNAL OF CLINICAL AND DIAGNOSTIC RESEARCH. doi: 10.7860/jcdr/2013/6980.3526.

S, M. P. et al. (2017) 'Knowledge and awareness of partial edentulism in rural population (kancheepuram)

- a survey', International Journal of Recent Scientific Research, pp. 16578-16580. doi: 10.24327/ ijrsr.2017.0804.0176.

Tao, X. et al. (2018) 'Comparison of Gingival Troughing by Laser and Retraction Cord', The International Journal of Periodontics \& Restorative Dentistry, pp. 527-532. doi: 10.11607/prd.3551.

Varghese, S. S., Ramesh, A. and Veeraiyan, D. N. (2019) 'Blended Module-Based Teaching in Biostatistics and Research Methodology: A Retrospective Study with Postgraduate Dental Students', Journal of dental education, 83(4), pp. 445-450.

$\mathrm{V}$, H. et al. (2017) 'Uses of cold plasma in conservative dentistry and endodontics', International Journal of Current Advanced Research, pp. 3848-3851. doi: 10.24327/ijcar.2017.3851.0380.

Wassell, R. et al. (2018) Extra-Coronal Restorations: Concepts and Clinical Application. Springer.

Xhonga, F. A. (1971) 'Gingival retraction techniques and their healing effect on the gingiva', The Journal of Prosthetic Dentistry, pp. 640-648. doi: 10.1016/00223913(71)90089-8. 